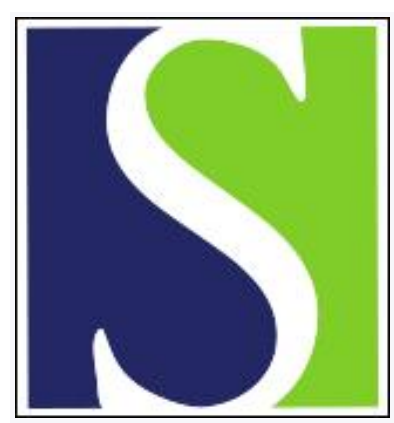

Scand J Work Environ Health 1983;9(6):511-513

https://doi.org/10.5271/sjweh.2382

Issue date: Dec 1983

White lead exposure among Danish police officers employed in fingerprint detection.

by Rabjerg L, Jennum PJ, Morck HI

This article in PubMed: www.ncbi.nlm.nih.gov/pubmed/6673108

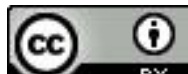




\title{
White lead exposure among Danish police officers employed in fingerprint detection
}

\author{
by Lene Rabjerg, MD, Poul J Jennum, MD, Henning I Mørck, MD
}

\begin{abstract}
RABJERG L, JENNUM PJ, MORCK HI. White lead exposure among Danish police officers employed in fingerprint detection. Scand $j$ work environ health 9 (1983) 511-513. White lead is often used by police officers employed in fingerprint detection (dactylography). On the basis of a case of mild lead intoxication in a police officer all 22 exposed police officers at the Bureau of Dactylographic Identification in Copenhagen were examined. All went through a clinical examination and blood lead determination. None of the participants showed any sign of lead intoxication. The median blood lead concentration was $0.97 \mu \mathrm{mol} / 1(10 \mathrm{th}-90$ th percentiles $0.72-1.44 \mu \mathrm{mol} / \mathrm{l})$, a value definitely higher than the average of the general population matched for age and sex. A correlation between the weekly white lead exposure and blood lead concentration $(r=0.87, p<0.0001)$ was found among the participants.
\end{abstract}

Key terms: lead intoxication, police work.

Lead exposure of policemen employed in traffic regulation (1) and in shooting instruction (2) has been reported. Another rare and scarcely noticed lead exposure among police officers is white lead dust, which is used in fingerprint detection (dactylography). The latter was first described in Denmark in 1937 (3). The US Public Health Service (5) has listed 113 occupations with potential lead exposure, but dactylographs are not included in the list.

Recently we saw a case of mild lead poisoning most likely caused by the use of white lead in fingerprint detection and found it of interest to determine whether this special kind of lead exposure is still of relevance.

\section{Case history}

A 36-year-old police officer was admitted in January 1982 to the Clinic of Occupational Medicine, Rigshospitalet, Copenhagen, with a high blood lead level found by his physician. In his work the policeman was often exposed to white lead detecting latent fingerprints at the site of

1 Clinic of Occupational Medicine, Rigshospitalet, Copenhagen, Denmark.

Reprint requests to: Ms L Rabjerg, Arbejdsmedicinsk klinik, Rigshospitalet, Tagensvej 18, DK-2200 Copenhagen N, Denmark. crimes. He had never been employed in the traffic department or as a shooting instructor, and he had no other known exposure to lead. For some time, and especially during the last three months prior to the examination, he worked increasingly with white lead. One month before admission he suffered from stom. ach pain, obstipation, and ill health and was unfit to continue daily work. The blood lead concentration determined by his physician was $2.75 \mu \mathrm{mol} / 1$. One month later we found a blood lead concentration of $2.41 \mu \mathrm{mol} / \mathrm{l}$. The physican reported a rapidly declining value, and the blood lead concentration was $0.97 \mu \mathrm{mol} / \mathrm{l}$ after five months. None of the patient's family members had high blood lead levels, determined to rule out household exposure.

\section{Subjects and methods}

Population. In the Bureau of Dactylographic Indentification in Copenhagen we invited 22 police officers, all exposed to white lead, to participate in our investigation. The participation rate was $100 \%$. The population consisted of males only with an arithmetic mean age of 36 (range 27-68) years.

Exposure. The technique of exposing fingerprints implies, first, the dusting of 


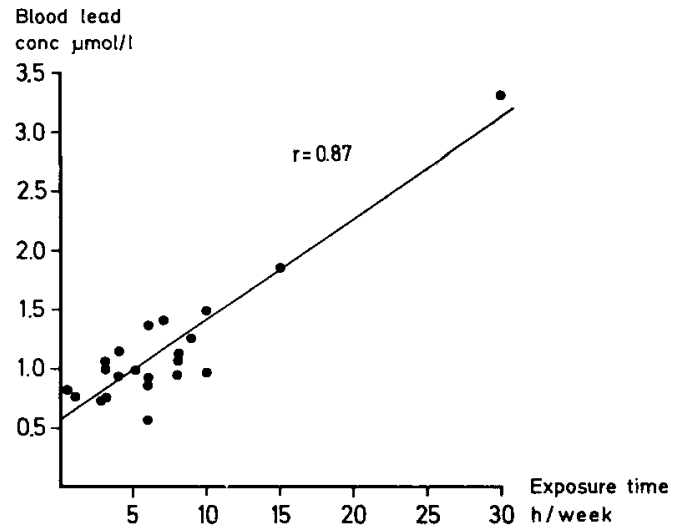

Fig 1. Correlation of blood lead concentration (conc) and exposure to white lead in fingerprint detection work.

furniture and other effects with white lead and, second, the brushing away of the excess powder. Thereby the fingerprints become visible. During work several of the police officers had noticed a sweet taste, which indicates ingestion of white lead.

Procedure. A questionnaire was sent to all the men employed in the identification office. This prefilled questionnaire contained information on previous symptoms and diseases and standardized questions about every organ system, including the cerebral nervous, cardiopulmonary, and gastrointestinal systems. In addition information on previous occupational status was given to us by interview.

Especially information on possible previous and present lead exposure was obtained. In addition to the interview a physical examination was made. It consisted of blood pressure recordings and estimations of lung function by the use of a WrightMackerrow ${ }^{\circledR}$ peak flow meter. Venous blood samples were drawn and analyzed for blood lead concentration. The samples were processed on the day of the examination by the use of a micromethod iead determination technique (4).

\section{Results}

In fig 1 the correlation between the blood lead concentrations of the 22 male police officers and the white lead exposure time per week in hours is shown. A statistically significant correlation was found $(r=0.87$; $\mathrm{p}<0.0001)$. The median blood lead concentration of our population was 0.97 $\mu \mathrm{mol} / \mathrm{l}$ (10th-90th percentiles 0.72-1.44 $\mu \mathrm{mol} / \mathrm{l})$. None of the men had any symptoms that, with reason, could be ascribed to lead intoxication, and all were in excellent condition healthwise.

\section{Discussion}

In this investigation all the participants were occupationally exposed to white lead. None of the men were otherwise exposed. A correlation between hours of exposure per week and blood lead level was found, indicating a fairly constant exposure in dactylography. In an unselected population of 40-year-old men the median value for workers employed in industry was 0.63 $\mu \mathrm{mol} / \mathrm{l}$ (10th-90th percentiles $0.43-0.97$ $\mu \mathrm{mol} / \mathrm{l})(4)$. Workers employed in the construction industry had a median value of $0.68 \mu \mathrm{mol} / \mathrm{l}(10 \mathrm{th}-90 \mathrm{th}$ percentiles $0.43-$ $1.01 \mu \mathrm{mol} / \mathrm{l})$, and farmers had the median value of $0.33 \mu \mathrm{mol} / 1$ (10th $-90 \mathrm{th}$ percentiles 0.24-0.68 $\mu \mathrm{mol} / \mathrm{l})$. The median blood lead levels in unselected Danish men aged 40 was $0.62 \mu \mathrm{mol} / \mathrm{l}$. From these figures it appears that the blood levels of the policemen occupied with dactylography in our study were definitely higher than normal.

Our findings support Nyfeldt's findings from 1937 (3), that the use of white lead among dactylographs can be risky. However, none of the men we investigated suffered from lead intoxication, and only one man had a blood lead concentration over the present threshold limit value of $2.90 \mu \mathrm{mol} / \mathrm{l}$. The use of white lead in fingerprint detection should be restricted, especially because alternative dust types for the identification of fingerprints have been introduced (ferrodust, aluminium dust). If the use of white lead is necessary, the user should be advised to wear gloves and an effective dust mask.

\section{References}

1. Bisby JA, Ouw KH, Humphries M, Shandar AG. Absorbtion of lead and carbonmonooxide in Sydney traffic policemen. Med $j$ aust 1 (1977) $437-439$.

2. Landrigan GJ, McKinney AS, Hopkins LC, Rhodes WW, Price WA, Cow DH. Chronic lead absorbtion - Result of poor ventilation in an indoor pistol range. $\mathrm{J}$ am med assoc 234 (1975) 294-297. 
3. Nyfeldt AA. Et tilfælde af kronisk blyforgiftning. Ugeskr læg 99 (1937) 283-284.

4. Olsen NB, Hollnagel $\mathrm{H}$, Grandjean P. Indicators of lead exposure in an adult Danish surburban population. Dan med bull 28 (1981) $168-176$.

5. US Department of Health, Education and
Welfare. Occupational exposure to inorganic lead. Public Health Service, Center for Disease Control, National Institute for Occupational Safety and Health, Cincinnati, $\mathrm{OH}$ 1978.

Received for publication: 5 July 1983 